\title{
Cultural Values and Their Challenges for Enterprises
}

\author{
Shili Sun (Corresponding author) \\ Department of International Business, School of Foreign Languages Ludong University \\ No.186 Hongqi Middle Road, Zhifu District, Yantai 264025, Shandong Province, China \\ Tel: +86-535-668-5337Ｅ-mail: shilisun333@yahoo.com.cn \\ Zhongcen Xu \\ Department of English Language and Literature, College of Foreign Studies Liaoning University \\ No.38 Qingnian Street, Baita District, Liaoyang 111000, Liaoning Province, China \\ Tel: +86-419-422-9956 E-mail: xu_zc@163.com
}

Received: December 12, 2011 Accepted: January 28, 2012 Published: March 15, 2012

doi:10.5430/ijba.v3n2p68

URL: http://dx.doi.org/10.5430/ijba.v3n2p68

\begin{abstract}
In current enterprises, more and more employees have begun to feel that organizational cultures established many years ago are out of step with the contemporary values, thus, the need to determine which attributes of an organization's culture should be preserved and which should be modified is constant.

Due to the subtle change of cultural values among employees, some new challenges will occur simultaneously. Managers must have a complete and correct understanding about those values and challenges, so that they would balance the two effectively and efficiently, and boost their business development successfully.
\end{abstract}

Key words: Organizational Culture, Values, Challenges

\section{Introduction}

Cultural values, at the simplest level, are commonly shared concepts about what is right, wrong, possible or impossible, true or false and so on. From there, it gets complicated. For an enterprise, the arena of cultural values can be as small as each employee's personal set of decisions as to what is acceptable or not. They can be firmly set in deciding that existing cultural values are just fine and that no new or different ones are wanted or needed. They are also flexible and capable of adhering to the cultural values inside and outside their companies. Of course, sometimes they would have to be required to adjust values as their working environment and conditions change.

On the other hand, the arena of cultural values can also be as large as an entire enterprise or society full of people's shared values about what is acceptable or not (Elizabeth M. Young, 2009). In this sense, it is very difficult for those employees within an enterprise or those people in a society, for example, to agree on cultural values, but the cultural values that are externally imposed by national, provincial level, regional, and other smaller and smaller subsets of human and natural influences can become more and more shared as the subset of national identity becomes smaller and smaller, until they get to the family or individual unit of humanity.

In order to achieve a complete and precise recognition of various cultural values and their potential challenges, it's definitely crucial for those top or middle management to grasp an organizational culture's levels, challenges and types, which readers will find relevant discussions in details as follows.

\section{The Levels of Organizational Culture}

Organizational culture consists of many components. But, no component individually represents the culture of the organization. And only taken those attributes together might give us some insight into the nature of organizational culture.

In reality, Cummings and Worley's (1997) four levels of organizational culture can impress us with strong indication, which you can find more in details in Figure 1 at the end of this paper.

As we can see from the Figure 1, the least visible or deepest level is that of basic shared assumptions, which represent 
beliefs about reality and human nature that are taken for granted (Hellriegel et al, 2001). For example, what are the key thoughts in the development of reward systems; how to motivate employees effectively; how to control employees so as to enhance their performance, and so on.

And because those shared assumptions lie at the innermost core of a culture, Schein (1990) named them as 'basic assumptions'. For Schein, they are 'fundamental beliefs that are so taken for granted that most people in a cultural unit subscribe to them but not in a conscious way'.

The next level of culture is that of cultural values, which usually represent collective beliefs, assumptions, and feelings about what things are good, normal, rational, valuable, and so on (Silvester et al, 1999)

Normally, cultural values might be quite different in different organizations, and these values are not easy to change over time even when organizational membership changes. For example, employees may care deeply about money, but in some different organizations they may care more about technological innovation or employee well-being.

Sathe (1985) points out those cultural values consist of reasons or justifications for people behaving as they do. Unlike shared assumptions values are consciously held, they come directly from underlying assumption and are moral or ethical codes that guide behaviors to put the assumptions into practice (Rollinson, 1998).

The third level is that of shared behaviors, which are more visible and somewhat easier to change than values. Most of the reasons should be due to people's unawareness of the values that bind them together (Hellriegel et al, 2001).

Because norms are a code of behavior brought into being by the underlying assumptions and values (Rollinson, 1998), they are perpetuated when people observe them, thereby, norms are received as a part of shared behaviors. For example, if people only reach high positions by working a 60 -hour work, this sets up an expectation that these hours are a criterion for promotion, which might become accepted as the normal behavior for ambitious people.

The most superficial level of organizational culture consists of symbols. Cultural symbols are words (jargon or slang), gestures, and pictures or other physical objects that carry a particular meaning within a culture (Gamble \& Gibson, 1999). In Rollinson's eye, these are the most visible manifestations of a culture, and are defined as 'artefacts and creations'. They include everything from the physical layout of a building to the way people dress, the way they talk to each other and, often, the things they talk about.

In reality, despite it has been convenient to describe all these signs separately it is important to recognize that they complement each other and are often used in combination as reminders of what the culture is and what is expected (Harrison et al 1984). Rollinson (1998) also emphasizes that it can be dangerous to view them in isolation, because they often give vital clues about the underlying values and beliefs.

Moreover, there is a strong relationship between the different levels of culture. Shared assumptions and cultural values are often expressed in values, and in turn shared behaviors and cultural symbols are practical ways of expressing the values.

More importantly, the achievement of a good match between the values of the organization and employee is a two-part task. First, potential employees must figure out what the organization values. Second, potential employees must identify organizations that share their personal values (Hellriegel et al, 2001).

\section{The Challenges Facing Organizational Culture}

In reality, there are two major challenges from organizational culture, which might confront every organization: first, external adaptation and survival, and second is internal integration (Schein, 1985).

In seeking for further development, an organization will have to find proper ways to cope with its constantly changing external environment, so, external adaptation and survival become even more important. According to Hellriegel et al (2001), external adaptation and survival usually involves addressing the following issues:

- Mission and strategy: which aims to identify the primary purpose of the organization; and select appropriate strategies to pursue this mission.

- Goals: this normally set specific targets to achieve.

- Means: which determine how to achieve the goals, including selecting an organizational structure and reward system.

- Measurement: this establishes criteria to determine how well individuals and teams are accomplishing their goals.

Internal integration has to do with the establishment and maintenance of effective working relationships among the members of an organization. In Hellriegel et al's eyes (2001), there are four issues contained in internal integration:

- Language and concepts: which aims to identify methods of communication and develop a shared meaning for 
important concepts. In order to work together in an organizational setting, it has been suggested that people must develop mutual understanding through the common use of language and conceptual categories.

- Group and team boundaries: this aims to establish criteria for membership in groups and teams.

- Power and status: this aims to determine rules for acquiring, maintaining, and losing power and status.

- Rewards and punishments: this aims to develop systems for encouraging desirable behaviors and discouraging undesirable behaviors (Schein, 1990). Meanwhile, employees also learn about an organization's culture through its reward system. The rewards and punishments attached to various behaviors convey to employees the priorities and values of both individual managers and the organization.

In reality, only by discovering or developing ways of coping with issues of external adaptation and internal integration, the members of an organization might share knowledge and assumptions, and then an organizational culture is coming into being. One common pattern in the emergence of corporate culture was given in Figure 2 at the end of this paper.

\section{The Types of Organizational Culture}

Although there are kinds of cultures, and different culture is made up of different elements. However, organizational cultures have some common characteristics (Hellriegel et al, 1999).

According to Hooijberg et al (1993), there are four pure types of organizational culture: bureaucratic, clan, entrepreneurial, and market. One hand, one of these basic types of culture will be predominant within an organization; on the other hand, multiple cultures are likely not only to exist, but also to compete for superiority.

\subsection{Bureaucratic Culture}

Normally, an organization that values formality, rules, standard operating procedures, and hierarchical coordination has a bureaucratic culture.

In such an organization, tasks, responsibilities, and authority for all employees are clearly defined, and employees believe that their duty is to go and follow the organization's many rules, processes and procedures. Strictly speaking, bureaucratic culture has the same attributes as Handy's (1993) role culture, where rules and procedures are regarded as the major methods of influence.

\subsection{Clan Culture}

Tradition, loyalty, personal commitment, extensive socialization, teamwork, self-management, and social influence are attributes of a clan culture (Kerr \& Slocum, 1987). Working in such a culture, employees understand that contributions to the organization may exceed any contractual agreements. Because individuals believe that the organization will treat them fairly in terms of salary increase, promotions, and other forms of recognition, thereby, they hold themselves accountable to the organization for their actions.

In a clan culture, members share feelings of pride in membership; they have a strong sense of identification and recognize their interdependence. It is shared goals, perceptions and behavioral tendencies that foster communication, coordination, and integration for the organization's operation. Thus, teamwork, participation, and consensus decision making are believed to lead to the success for a clan organization.

\subsection{Entrepreneurial Culture}

Entrepreneurial culture is characterized with high levels of risk taking, dynamism, and creativity. One apparent attribute of this culture is that it creates change, rather than just quickly react to changes in the environment. Effectiveness under this culture means providing new and unique products and rapid growth. Individual initiative, flexibility, and freedom are the key factors to foster growth and are encouraged and are well rewarded.

That is to say, an entrepreneurial culture is an innovative culture, most companies like 3M, and Disney have had long histories of innovation and opportunity focus as cultural values, and these values have been institutionalized dramatically by numerous processes (Neal E, 2003), just as what Johannisson (1987a) describes, 'if the culture contains pro-entrepreneurial values, it serves as an incubator in the entrepreneurship's initiation process'.

Specifically, an entrepreneurial culture can't be created without the entrepreneur and entrepreneurship. The entrepreneur is motivated to create a venture which reflects their vision and ambitions, and entrepreneurship can be regarded as an instrument for changing the culture of an organization or the whole society, whereas entrepreneurial culture is used to express attitude towards commerce at a business level (Alison Morrison, 2000), so, it can support all entrepreneurial activities effectively and by different ways. 


\subsection{Market Culture}

The achievement of measurable and demanding goals, especially those that are financial and market-based, such as sales growth, profitability, and market share, they characterize a market culture (Hellriegel et al, 2001). In the literature history, market culture is also named as marketing culture or market-oriented culture, which are cited both from cultural perspective.

According to Webster (1993), marketing culture is 'the pattern of shared values and beliefs that help individuals understand the marketing function and thus provides them with norms for behavior in the firm ... in other words, the marketing culture of a service firm refers in the way marketing 'things are done in the firm'. Similarly, Harris (1998) defines a market-oriented culture as 'the dominant, dynamic segment of an organization whose orientation, attitudes and actions are geared towards the market'. In reality, a market-oriented culture being the marketing culture most closely focused on market (Deshpande et al, 1993).

Within a market culture, the organization doesn't promise security, and the individual doesn't promise loyalty. Meanwhile, market culture values independence and individuality, and encourages members to pursue their own financial goals.

All in all, as is true of organization designs, different organizational cultures may be appropriate under different conditions, with no one type of culture being ideal for every situation. However, some employees may prefer one culture to another. The fact is only those employees who work in organizations with cultures that fit their own view of an ideal culture tends to be committed to the organization and optimistic about its future.

\section{Conclusion}

Within a work environment, the cultural values that drive business decisions are critical to the organization's credibility with its employees, customers, and shareholders. Organizations of all kinds are being challenged to take a hard look at their own cultural dimensions and challenges. Right and wrong defined by different employee may manifest diverse thinking, motivated by each employee's personal values. We can't ignore that job satisfaction and employees' commitment to their organizations get close links with the cultural values in their enterprises. In practice, cultural values dominate an enterprise's daily operations, it is also concluded that cultural values could be an effective basis for decisions making, market segmentation, or any other operating or marketing activities.

\section{References}

Alison, M. (2000). Entrepreneurship: what triggers it? International Journal of Entrepreneurial Behaviour \& Research, Volume 6, Number 2, pp. 59-71. http://dx.doi.org/10.1108/13552550010335976

Cummings, \& Worley,. (1997). Organisation Development and Change. (6 ${ }^{\text {th }}$ Edition). South Western Publishing.

Deshpande, R., Farley, J. U. \& Webster, F. E. (1993). Corporate culture, customer orientation, and innovativeness in Japanese firms: a quadrad analysis. Journal of Marketing, 57, 23-7. http://dx.doi.org/10.2307/1252055

Elizabeth, M. Y. (2009). Aim Straight at the Fountain and Press Vaporize. Publisher: Fence Books.

Gamble, P. R. \& Gibson, D. A. (1999). Executive values and decision-making: The relationship of culture and information flows. Journal of Management Studies, 36, 217-227. http://dx.doi.org/10.1111/1467-6486.00134

Handy, C. (1985, 1993). Understanding Organisations. Penguin, Harmondsworth.

Hellriegel, D., Jackson, S, E. \& Slocum, J. W. Jr. (1999). Management. ( $8^{\text {th }}$ ed). Cincinnati: South-Western, 1999, 624-628

Hellriegel, S. \& Woodman,. (2001). Organisational Behavior. ( $9^{\text {th }}$ Edition). pp 523, South-Western.

Hooijberg, R. \& Petrock, F. (1993). On cultural change: Using the competing values framework to help leaders execute a transformational strategy. Human Resource Management, 32, 29-50. http://dx.doi.org/10.1002/hrm.3930320103

Johannisson, B. (1987). Anarchists and organizers: entrepreneurs in a network perspective. International Studies of Management and Organisations, XVII, 1, 49-63.

Kerr, J. \& Slocum, J. W., Jr. (1987). Managing corporate culture through reward systems. Academy of Management Executive, 1(2), 99-108. http://dx.doi.org/10.5465/AME.1987.4275817

Kotter, J.P. \& Heskett, J. L. (1992). Corporate Culture and Performance. New York: Free Press.

Lloyd, C. H. (1998). Cultural domination: the key to market-oriented culture? European Journal of Marketing, Volume 32, Number 3/4, pp. 354-373. http://dx.doi.org/10.1108/03090569810204643 
Neal E. T. (2003). Corporate entrepreneurship: teaching managers to be entrepreneurs. The Journal of Management Development, Volume 22, Number 4, pp. 329-344. http://dx.doi.org/10.1108/02621710310467613

Rollinson, E. \& Broadfield,. (1998). Organisational behaviour and analysis. pp535, Addison Wesley.

Sathe, V. (1985). Culture and Related Corporate Realities: Text, Cases and Readings on Organizational Entry, Establishment and Change. Homewood Ill: Irwin.

Schein, E. H. (1985). Organisational Culture and Leadership. Jossey Bass, San Francisco.

Schein, E. H. (1990). Organisational culture. American Psychologist, 45, 109-119. http://dx.doi.org/10.1037/0003-066X.45.2.109

Silvester, J., Anderson, N., \& Patterson, F. (1999). Organisational Culture change: An inter-group attributional analysis. Journal of Occupational and Organisational Psychology, 72, 1-3. http://dx.doi.org/10.1348/096317999166464

Webster, C. (1993). Refinement of the marketing culture scale and the relationship between marketing culture and profitability of a service firm. Journal of Business Research, 26, 111-31. http://dx.doi.org/10.1016/0148-2963(93)90001-6

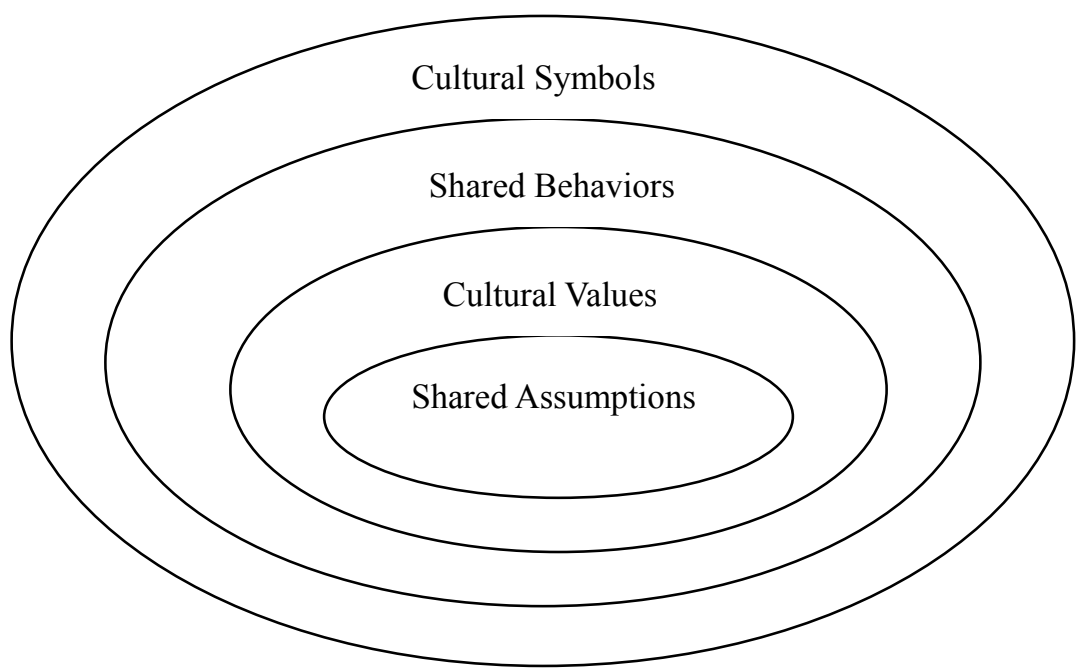

Figure 1. Levels of organizational culture

Source: Cummings and Worley (1997) 


\section{Top Management}

A top manager or team develops and attempts to

implement a shared vision and business strategy

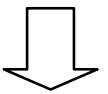

\section{Organisational Behaviour}

Implementation is successful. Employees behave in ways

that are in agreement with the shared values and business strategy

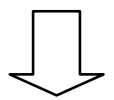

\section{Results}

The organisation is successfully based on standard financial and performance indicators

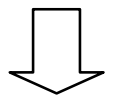

\section{Culture}

A culture emerges that reflects the vision, strategy, and experiences of people in the organisation. This culture describes the behaviours that are acceptable and unacceptable and the traditions that will be maintained.

Figure 2. One Common Pattern in the Emergence of Corporate Culture

(Source: Adapted from Kotter, J.P., and Heskett, J.L. Corporate Culture and Performance. New York: Free Press, 1992, 8.) 